https://doi.org/10.18485/iipe_response2covid19.2021.ch5

\title{
THE RIGHT TO COMPENSATION FOR BUSINESS RESTRICTIONS FRAMED BY HUMAN RIGHTS AND STATE AID RULES ${ }^{1}$
}

\begin{abstract}
Ondrej Blažo²
Adam Máčaj ${ }^{3}$

Abstract: State regulations restricting a certain type of business or a certain type of business activity are considered by the European Court of Human Rights (ECtHR) as a "control of use" rather than a "deprivation of ownership" case, i.e., de facto expropriation. In this context, the ECtHR provides an analysis of the relationship between Art. 1 of Protocol No. 1 and such "control of use". This case law can be recalled in the context of measures adopted in the fight against the COVID-19 pandemic.

For the purpose of compensating the restrictions on the use of property, all instruments which have as their object or effect the alleviation of the burden of a public health measure on the entrepreneur must be taken into account. These instruments may therefore also fall within the scope of the European Union competition rules since distortions of competition through state aid are not compatible with the internal market. The presented research aims to assess and evaluate the responses of the European Union Member States vis-à-vis compensation state aid schemes, compare methods of compensation schemes notified by the EU Member States, and assess solidarity in respective MS based on the value of compensation schemes.
\end{abstract}

Keywords: European Convention on Human Rights, EU State Aid Rules, compensation schemes, business restrictions.

${ }^{1}$ This contribution presents some results from research projects: APVV-17-0641 "Improvement of the effectiveness of legal regulation of public procurement and its application within the EU law context".

${ }^{2}$ Associate Professor, Institute of European Law, Comenius University in Bratislava Faculty of Law, Šafárikovo nám.681000 Bratislava, Slovakia, ondrej.blazo@flaw.uniba.sk.

${ }^{3} \mathrm{PhD}$ Candidate, Institute of European Law, Comenius University in Bratislava Faculty of Law, Šafárikovo nám.6810 00 Bratislava, Slovakia, adam.macaj@flaw.uniba.sk. 


\section{INTRODUCTION}

The outbreak and subsequent raging pandemic of COVID-19 proved difficult to rein in, with virtually all member states of the European Union (EU) adopting various restrictions, protecting their citizens but at the same time causing "unfortunate collateral damage to the economy" (Van Hove, 2020, p. 15). These restrictions and subsequent economic losses naturally clash with the interests of business operators to carry on with their activities, which fall under the protection of the right to property recognized under Art. 1 of Protocol No. 1 (P1) of the European Convention on Human Rights (ECHR). These restrictions are considered by the European Court of Human Rights (ECtHR) as so-called "control of use" cases, rather than de facto expropriation or "deprivation of ownership". To consider these restrictions compatible with human rights, there must be, above all, a fair balance between the general interest of society and the requirement to protect the fundamental rights of the individual.

The proportionality test must also assess whether, as a result of the measures, the trader did not bear an "individual and excessive burden". The ECtHR considers, for example, the residual value of assets and their retention, or general compensation schemes in the assessment of this burden in order to determine whether the interference with the property of the business was proportionate. The role of compensation is particularly important in this regard, whether through a flat-rate compensation, a rescue mechanism sold to an industry, or when the entrepreneur's assets did not substantially lose value, as the entrepreneur could repurpose them.

As compensation for such interference, all instruments that have as their object or effect the alleviation of the burden of a public health measure on the trader are considered. Under such a broad view of compensation, these instruments may therefore also fall within the scope of the EU competition law since, according to Art. 107(1) of the Treaty on the Functioning of the European Union (TFEU), distortions of competition through state aid are not compatible with the internal market. By reflecting on the role compensations have in protecting the right to property of business operators, and assessing intertwined compensation schemes safeguarding the right to property, and regulation of state aid in the EU, this research aims to assess and address these problems in order to:

1) Evaluate the response of the EU vis-à-vis compensation state aid schemes;

2) Compare the methods of compensation schemes notified by the EU Member States and assess solidarity in respective MS based on compensation schemes' value. 


\section{RESTRICTIONS OF BUSINESS ACTIVITY AND THEIR COMPATIBILITY WITH THE EUROPEAN CONVENTION ON HUMAN RIGHTS}

Apart from causing a global health crisis, the COVID-19 pandemic has resulted in significant shifts in views on governments' permissible interferences in the entire spectrum of human rights. The need to contain the pandemic is constantly at risk of morphing into the any-means-necessary approach, where pandemic countermeasures are adopted without any considerations as to their necessity or proportionality (Thomson \& Ip, 2020, p. 16). The measures span across a broad range of interferences. One significant impact that needs close assessment is the conduct of business activities and restrictive measures placed on them during the pandemic. While these restrictions address an entirely new crisis, their compatibility with human rights of business operators can, nevertheless, be assessed through the jurisprudence of the ECtHR, which has repeatedly considered such restrictions throughout its existence, albeit the rationale behind the challenged restrictions often varied considerably from the public health crises represented by COVID-19 nowadays.

One of the recent landmark judgments of the ECtHR concerning the right to property and interferences with business activities is the case of O'Sullivan McCarthy Mussel Development Ltd. v. Ireland. The case concerned restrictions adopted by Ireland in order to give effect to EU environmental law instruments, which had the result of depriving the applicant company of the opportunity to fish for mussel seeds, even when the necessary license for fishing had been obtained by the applicant company. When assessing the alleged violation of the right to property and peaceful enjoyment of possessions in the context of freedom to conduct business activities, the ECtHR had no difficulty in considering economic interests in business activities requiring a licence or a permit to fall within the scope of Art. 1 $\mathrm{P} 1{ }^{4}$ and found, in accordance with its jurisprudence, interference with the right to property even where the applicant company was not deprived of any licences, as the measures of respondent state have nevertheless restricted the usual conduct of the business licence was issued for. The ECtHR followed its case law dating back to the older right to property cases dealing with, for example, real estate expropriation (Sporrong and Lönnroth v. Sweden (Plenary), app. nos. 7151/75 and 7152/75, 23 September 1982, § 61 et seq.), considering which of the three separate tests to use when dealing with restrictions on business activities. In an approach similar to the lex specialis doctrine, the ECtHR first considers whether a deprivation of possessions has occurred or control of the use of the property for the purposes

\footnotetext{
${ }^{4}$ See also Werra Naturstein GMBH \& CO KG v. Germany, app. no. 32377/12, 19 January 2017, § 37.
} 
of safeguarding the public interest. Only if neither the second sentence of Art. 1(1), nor Art. 1(2) P1 applies, will the ECtHR proceed with assessment of the general principles under the protection of peaceful enjoyment of possessions and interferences therewith (Sporrong and Lönnroth v. Sweden, § 61.).

Based on the well-established positions of the ECtHR jurisprudence when it comes to considerations of state interference in business activities which renders them partially or wholly impossible, it can therefore be concluded that virtually all of the measures and restrictions adopted throughout the time of the SARS-CoV-2 pandemic in the Council of Europe Member States that had an impact on business would fall within the category of control of property use. Even if the measures would mean that the business concerned is forced to limit, halt, or stop its operations, or even close down permanently, they would not lose any economic interest to such an extent that would warrant a finding of a deprivation of property by the ECtHR. Only the most extreme cases of draconic restrictions, which would not only effectively deprive the business of the possibility to operate, or force it to wind up its activities, but in fact deprived it of access to its assets or real estate, would potentially be considered outside the second paragraph of Art. 1 P1, as a deprivation of property.

Nevertheless, the second paragraph still maintains strict criteria for any control of property use, which it must fulfil in order to shield the state measures from a violation of the right to property under the ECHR. The wording of the second paragraph itself does not provide any criteria for interference with the property that used to be considered compatible with the ECHR, unlike many substantive provisions. The general interest authorizes state parties to control the use of property without any specific curtailments of this power. Nevertheless, the test of lawfulness is found in the provision dealing with the deprivation of property limb of Art. 1, as well as many other provisions, and has been applied by the ECtHR even in control of use cases (O'Sullivan McCarthy Mussel Development Ltd. v. Ireland, $\S$ 107). Similarly, the requirement of general interest asks the states to justify their interference with the pursuit of some legitimate aim or purpose (Bélané Nagy v. Hungary (GC), app. no. 53080/13, 13 December 2016, § 113). Finally, the interference must be proportionate in order not to constitute a violation of the right to property. An individual concerned must not bear an individual and excessive burden, disproportionate to the aims sought to be achieved by the state (James and others v. the United Kingdom (Plenary), app. no. 8793/79, 21 February 1986, § 50). The same requirement of proportionality applies to both, the deprivation-ofpossession cases and the control-of-use cases, as the requirement of balancing the right to property against the interests of society is reflected in Art. 1 P1 as a whole (Werra Naturstein GMBH \& CO KG v. Germany, § 45). However, the ECtHR 
traditionally leaves states with a margin of appreciation to adopt the desired measures, and in cases of business activities, the margin afforded is a wide one (Ouzounoglou v. Greece, app. no. 32730/03, 24 November 2005, § 29).

In assessing whether such a margin has been respected, the ECtHR pays attention to all the individual circumstances of specific cases, without following an exact checklist of facts, which makes it naturally more complicated to predict the specific cases of pandemic restrictions that would fail the proportionality test. Nevertheless, the existing case law identifies several factors recognized in the past as vital when dealing with proportionality assessment under Art. 1 P1. First and foremost, for the purpose of this paper, is the role that payment of compensation and compensatory schemes have in balancing the burden placed on economic operators and the interests of the state to halt, or at least weaken, the pandemic.

It is precisely at this point where the relevance of distinguishing between deprivation of property and control of use cases plays a vital role in assessing the proportionality of state interference. Despite the requirement of proportionality in both paragraphs of Art. $1 \mathrm{P} 1$, only in the case of deprivation of property, the lack of compensation would mean, save for exceptional situations, a per se finding of a violation of the right to property (James and others $v$. the United Kingdom, $§ 54)$. In control of use cases, on the other hand, the lack of compensation is "not of itself sufficient to constitute a violation [of the right to property]" (Depalle v. France (GC), app. no. 34044/02, 29 March 2010, § 91). Nevertheless, lack of compensation for restrictive measures plays an important role in the contribution to finding the measures disproportionate and arbitrary control of use (Vékony v. Hungary, app. no. 65681/13, 13 January 2015, § 35.EU:C:2011:368, § 175), especially where lack of compensation is accompanied by the absence of judicial remedies (Könyv-Tár Kft. And others v. Hungary, app. no. 21623/13, 16 October 2018).

Thus, it is apparent that in cases of pandemic restrictions, unless they arise to the level of property deprivation, the states could get away with the failure to introduce any type of compensation, provided that some other factors in the potential cases brought before the ECtHR or national courts do not tip the scales of the proportionality test towards finding the measures in their cumulative effect, including lack of compensation supplemented with other harm to litigants, to create a burden too excessive.

Additionally, some other criteria considered by the ECtHR further provide a stronger position for the states adopting pandemic restrictions. For one, temporarily limited restrictions tackling an unexpected crisis are appreciated more favourably by the proportionality test than permanent interferences with property (European Court of Human Rights, Savickas and others v. Lithuania, app. nos. 66365/09, 12845/10, 29809/10, 29813/10, 30623/10, 28367/11, 15 October 2013, § 94). 
Moreover, the restrictions adopted on a systematic basis and without singling out specific operators also make the burden placed on business not individual and excessive, and therefore contribute to finding the interference proportionate (Hentrich v. France, app. no. 13616/88, 22 September 1994, § 49). Finally, the temporal aspect of the proportionality assessment manifests itself even through the material time when the harmed business has invested in its property, and the risks it assumed at the time. When the person concerned knows, at the time of acquiring the property, about its restrictions and even the mere possibility of future restrictions, the said factor is considered as yet another reason contributing to finding the interference proportionate (Matczyński v. Poland, app. no. 32794/07, 15 December 2015, § 106).

In practice, this could even mean two categories of prospective applicants and two different kinds of outcomes if they appeared before the ECtHR. Applicants with property acquired before the pandemic and being hit with the restrictions could argue they could not foresee them when acquiring property, while the states could try and derail applications of those acquiring property from 2020 onward, arguing that they knew of the possibility of returning restrictions in an ongoing pandemic.

In sum, businesses harmed by restrictions imposed in the aftermath of a raging pandemic can argue that the lack of compensation violated their right to property, but they will almost certainly face an uphill battle in proving the measures were disproportionate. That being said, it is no surprise that the absence of the right to seek compensation from the viewpoint of international and European human rights standards is not reflected in the absence of such compensation schemes. In fact, such schemes, in various forms, are quite common, but also controversial from the viewpoint of compatibility with the rules of the EU on state aid, as explained below.

\section{GENERAL REMARKS ON EU STATE AID AND CRISIS SOLUTIONS}

In general, the TFEU forbids state aid which distorts or threatens to distort competition and affects trade between Member States (Art. 107(1), due to the broad understanding of the effect on trade by the European Commission (Cortese, 2020, pp. 12-14), the proving exemptions under Art. 107(2) TFEU (automatic exemptions) or Art. 107(3) TFEU (conditional exemption).

In the context of economic consequences of the COVID-19 pandemic, the majority of measures adopted by the Member States in order to support undertakings can seek a haven, particularly under Art. 107(2)(b) TFEU, i.e., "aid to make good the damage caused by (...) exceptional occurrences", or under Art. 107(3)(b), i.e., "aid (...) to remedy a serious disturbance in the economy of a Member State". 
Since state aid under Art. 107(2)(b) TFEU is exempted from prohibition automatically, it must be interpreted narrowly under constant case law of the Court of Justice of the European Union (CJ EU). ${ }^{5}$ Contrary to the exception under Art. 107(3) TFEU, in the cases of exemptions under Art. 107(2) TFEU, the Commission has no discretion power regarding the assessment of the state aid. Thus, Art. 107(2) TFEU "covers aid which is, in law, compatible with the common market, provided that it satisfies certain objective criteria. It follows that the Commission is bound, where those criteria are satisfied, to declare such aid compatible with the common market, and that it has no discretion in that regard" (Judgment of 25 June 2008, Olympiaki Aeroporia Ypiresies/Commission, T-268/06, EU:T:2008:222, § 51). This objective criterion is based on the strict limits of the purpose and scope of the aid, since "only economic disadvantages directly caused by natural disasters or by exceptional occurrences qualify for compensation as provided for in that provision" (Greece/Commission, C-278/00, § 82). The requirement of an apparent causal link covers both direct consequences of natural disasters or exceptional occurrences and the scale of the state aid itself: "It follows that there must be a direct link between the damage caused by the exceptional occurrence and the State aid and that as precise an assessment as possible must be made of the damage suffered by the producers concerned" (Atzeni and others, C-346/03 and C-529/03, § 79). If the state aid falls out of the exception under Art. 107(2) TFEU, it can still be covered by Art. 107(3) TFEU. However, in such a case, it is subject to scrutiny and discretion of the Commission regarding the assessment of the impact on trade between the Member States, impact on competition, and balance between negative consequences of the aid and its proportionality to achieve its aim. Regardless of the test's quality, both types of aid must be reported to the Commission (EU, 2015).

Concerning the test under Art. 107(2)(b) TFEU, the CJ EU explained the notion of "natural disaster and exceptional occurrences" broadly, i.e., it did not refer to a natural disaster or another equivalent occurrence, but also to measures adopted by public authorities in order to mitigate the effects of such an event itself or prevent its immediate reappearance. For example, the terrorist attacks of September 11th, 2001 were classified as exceptional occurrences, as was the closure of the airspace (Olympiaki Aeroporia Ypiresies/Commission, T-268/06, § 49). The CJ EU did not consider Art. 107(2)(b) to be applicable in the following cases:

\footnotetext{
${ }^{5}$ Judgment of 23 February 2006, Atzeni and others, C-346/03 and C-529/03, EU:C:2006:130, § 79; Judgment of 11 November 2003, Spain/Commission, C-73/03, EU:C:2004:711, § 36; Judgment of 29 April 2004, Greece/Commission, C-278/00, EU:C:2004:239, § 81; Judgment of 9 June 2011, Comitato "Venezia vuole vivere"/Commission, C-71/09 P, C-73/09 P and C-76/09 P, EU:C:2011:368, § 175.
} 
- the aid measures were to compensate for the difficulties relating to a crisis in the market concerned and high-interest rates, but those phenomena are the expression of the market forces which must be faced by any business (Atzeni and others, C-346/03 and C-529/03, § 80);

- the aid that was not reserved for farmers who had lost all of their animals but was granted if the loss was at least $20 \%$ of the animals (Atzeni and others, C346/03 and C-529/03, § 82);

- the state has provided no evidence of a link between the aid provided and the losses sustained (Atzeni and others, C-346/03 and C-529/03, § 82);

- the tax credit on the sale of rustic properties and the credit on loans and guarantees that were granted on the basis that the land was sold or the loans were requested, regardless of the damage suffered, cannot constitute compensation for the sharp increase in the price of fuel (Spain/Commission, C73/03, §38);

- the aid was granted to milk producers' cooperatives due to a market collapse following the Chernobyl nuclear disaster. Greece has not been able to establish a direct link between that aid and the Chernobyl nuclear disaster, nor has it been established that the amounts of aid granted to cooperatives actually corresponded to losses incurred to the members of the cooperatives as a result of the Chernobyl nuclear disaster, or that the measure was rather broad, covering all interventions of social character (Greece/Commission, C-278/00, § 77-89);

- measures designed to safeguard Venice, an important project of European interest, given that the reductions in social security contributions at issue are proportionate to the wage bill and are not designed to remedy the damage caused by natural catastrophes or other events of extraordinary nature, as the said provision requires, disregard the problem of 'acqua alta', which had to be regarded as a natural calamity (Comitato "Venezia vuole vivere"/Commission, C-71/09 P, C-73/09 P and C-76/09 P, § 175).

\section{EU STATE AID RULES VIS-À-VIS COVID-19}

During the COVID-19 pandemic, the EU adopted a multitude of measures aiming to mitigate the economic consequences of the pandemic and the economic consequences of measures of public health protection. These measures have been adopted either within the competence of the EU or within the competence of the Member States in line with the EU legislation. 
The most prominent measure of the former group is the NextGenerationEU recovery plan with its Recovery and Resilience Facility (EU, 2020c) accompanied by the Multiannual Financial Framework 2021-2027 (EU, 2020b). These instruments, apart from unprecedented recovery measures for the EU economy, also introduced structural measures within the EU, including enforcing the European Green Deal and strengthening the rule of law (EU, 2020d).

The focus of this chapter will be, however, on "micro solutions", i.e., not the recovery of the EU as a whole, but measures of the Member States as scrutinized by EU law. As explained before, the Member State that adopts some restrictive measures on business activities is to some extent legally obliged to introduce some measures relieving the burden imposed on businesses. Since such measures usually fulfil the criteria of state aid under Art. 107(1) TFEU, they must be reviewed for fulfiling exceptions from the prohibition under Art. 107(2) and (3) TFEU. It is apparent that the COVID-19 pandemic and state measures adopted in order to protect the health of people can be covered by the notion of "exceptional occurrences" under Art. 107(2) TFEU and compensation for these state measures can escape prohibition insofar as they cover a precise amount of damage causally linked with the restrictive measure at issue. Outside this scope, the Member States can revive their economies via aid under Art. 107(3) if they pass the assessment of the Commission. The Commission declared its preparedness to help the Member States with the swift introduction of state recovery and resilience instruments in order to cover damages causally linked to business disruption stemming from antiCOVID-19 actions as well as to spare businesses located in their territories from definitive and unrepairable closures (Ferri, 2021, p. 177). In order to facilitate the approval process (EU, 2015), the Commission did not follow the path of a possible temporary block exemption regulation, but a de facto block exemption communication - Temporary Framework for State Aid Measures (EU, 2020a). This framework does not replace existing "hard law" but facilitates its application, introduces procedural simplification, types and "templates" for state ait that can be speedily approved by the Commission (Bouchagiar, 2021).

In the context of the anti-pandemic measures, the Commission provides guidance regarding the distinction between aid under Art. 107(2)(b) TFEU and aid under Art. 107(3) ZFEU:

Under Art. 107(2)(b) TFEU, the Member States can cover damage directly caused by restrictive measures precluding the beneficiary, de jure or de facto, from operating its economic activity or a specific and severable part of its activity, i.e., measures which require, for example:

- the complete cessation of economic activity (e.g., the closure of bars, restaurants, or non-essential shops) or its cessation in certain areas (e.g.,--- 
restrictions on flights or other transport to or from certain points of origin or destination);

- the exclusion of certain highly material categories of clients (e.g., leisure travellers as far as it concerns hotels, school trips, and dedicated youth accommodation);

capping attendance for specific sectors or activities (e.g., entertainment, trade fairs, sports events) at levels demonstrably and materially below those that would be dictated in that specific setting, by generally applicable social distancing rules or rules on capacity in commercial spaces (e.g., because it does not appear sufficiently certain that protocols can be devised and successfully applied to ensure respect for the generally applicable measures in such settings) (EU, 2020a).

Under the Temporary Framework, other restrictive measures (for instance, general social distancing measures or general sanitary constraints, including measures merely translating such general requirements in terms specific to the characteristics of certain sectors or types of venues) would not seem to meet the requirements of Article 107(2)(b) TFEU. (EU, 2020a).

In order to estimate the financial scope of the state aid measures approved by the Commission in the period between 2020 and the first semester of 2021, published data on state aid approved within the Temporary Framework, as well as COVID-19-related aid approved due to Art. 107(2)(b) and (3)(b) and (c) TFEU (European Commission, 2021b). The list of the cases taken into account is in the annex of this paper. Indeed, these figures are not final since they do not cover nonnotified state aid (i.e., state aid under the general block exemption regulation or de minimis state aid) and state aid that was not notified due to the failure of the Member States to fulfil their duties. Furthermore, not all data for all schemes were available at the time this paper was prepared (July 2021), so all analysis is based solely on publicly available information. It must also be added that the figures refer to the total amount of the scheme or aid at issue, not to the aid corresponding to a certain year. Nevertheless, even though these shortcomings exist, Table 1 shows an unprecedented boost in the scale of state aid in 2020 compared to previous years. 
Table 1: Total amount of state aid granted in 2015-2019 and measures approved in relation to the COVID-19 pandemic in 2020-2021 (in millions of euros)

\begin{tabular}{|c|c|c|c|c|c|c|c|}
\hline & \multicolumn{5}{|c|}{ State aid in total (in mil. Euro) } & \multicolumn{2}{|c|}{$\begin{array}{c}\text { Covid-19-related } \\
\text { measures only }\end{array}$} \\
\hline & 2015 & 2016 & 2017 & 2018 & 2019 & 2020 & $\begin{array}{c}2021 \\
\text { (I.sem) }\end{array}$ \\
\hline Belgium & 1990,22 & 2550,12 & 2227,6 & 3636,81 & 4493,4 & 65702,25 & 1487,62 \\
\hline Bulgaria & 615,28 & 615,02 & 691,37 & 555,8 & 257,11 & 1527,90 & 135,20 \\
\hline Czechia & 2007,01 & 2310,13 & 2702,74 & 3374,25 & 2984,4 & 26570,40 & 11703,00 \\
\hline Denmark & 3293,45 & 4516,33 & 4471,39 & 4650,03 & 4379,05 & 14858,00 & 4444,10 \\
\hline Germany & 37165,65 & 42045,38 & 44707,86 & 48760,2 & 53023,51 & 806776,00 & 23892,00 \\
\hline Estonia & 193,86 & 172,48 & 235,86 & 266,05 & 326,94 & 3645,00 & 139,40 \\
\hline Ireland & 486,99 & 461,24 & 569,98 & 529,07 & 830,74 & 2948,00 & 211,00 \\
\hline Greece & 2350,75 & 825,36 & 497,76 & 550,03 & 983,15 & 16893,53 & 4377,80 \\
\hline Spain & 2332,8 & 2462,8 & 3056,59 & 4132,48 & 3894,34 & 76700,00 & 10000,00 \\
\hline France & 15882,7 & 15376,59 & 21580,21 & 21168,45 & 20530,07 & 391894,65 & 27205,00 \\
\hline Croatia & 262,42 & 464,33 & 607,1 & 793,32 & 699,89 & 2257,00 & 202,40 \\
\hline Italy & 2944,83 & 3289,9 & 4166,6 & 7357,27 & 6251,79 & 82272,01 & 10458,14 \\
\hline Cyprus & 120,36 & 119,13 & 105,64 & 98,15 & 103,77 & 344,47 & 325,20 \\
\hline Latvia & 781,22 & 593,93 & 442,14 & 291,29 & 299,65 & 875,91 & 340,85 \\
\hline Luxembourg & 175,38 & 181,88 & 144,76 & 143,26 & 167,75 & 3454,12 & 61,00 \\
\hline Hungary & 1366,49 & 2427,67 & 3255,99 & 2787,64 & 2434,6 & 8289,00 & 5475,20 \\
\hline Malta & 130,94 & 124,18 & 178,8 & 417,37 & 244,62 & 818,22 & 750,00 \\
\hline Netherlands & 1947,79 & 2243,18 & 2378,52 & 2689,98 & 2705,53 & 30219,70 & 8807,20 \\
\hline Austria & 1791,51 & 1831,9 & 1814,13 & 1749,07 & 1812,7 & 55296,40 & 395,00 \\
\hline Poland & 3396,66 & 4531,78 & 6946,92 & 5589,58 & 5440,89 & 61332,20 & 7377,30 \\
\hline Portugal & 871,66 & 706,14 & 1004,9 & 1073,16 & 961,84 & 18198,40 & 1640,00 \\
\hline Romania & 1233,27 & 1084,28 & 949,66 & 1110,33 & 1430,22 & 5510,60 & 546,61 \\
\hline Slovenia & 433,29 & 326,38 & 367,69 & 403,2 & 399,35 & 6406,70 & 46,36 \\
\hline
\end{tabular}




\begin{tabular}{|l|r|r|r|r|r|r|r|}
\hline & \multicolumn{5}{|c|}{ State aid in total (in mil. Euro) } & \multicolumn{2}{c|}{$\begin{array}{c}\text { Covid-19-related } \\
\text { measures only }\end{array}$} \\
\hline & \multicolumn{1}{|c|}{2015} & 2016 & 2017 & 2018 & 2019 & 2020 & $\begin{array}{c}2021 \\
\text { (I.sem) }\end{array}$ \\
\hline Slovakia & 415,51 & 361,8 & 257,05 & 425,47 & 562,02 & 6434,80 & 1098,00 \\
\hline Finland & 1587,59 & 1660,59 & 1870,01 & 1924,28 & 1866,05 & 6646,00 & 871,00 \\
\hline Sweden & 3149,83 & 3630,86 & 4397,24 & 4280,2 & 3802,37 & 17850,50 & 8374,30 \\
\hline EU & 87233,07 & 95236,56 & 110098,11 & 119444,08 & 121706,081 & 715880,06 & 130646,48 \\
\hline
\end{tabular}

Source:(European Commission, 2021a, 2021b) and authors

The intensity of state aid has been unevenly distributed, and the EU Member States have employed different strategies. Table 1 shows the absolute amount of state aid in respective years, and Chart 1 compares it to the gross domestic product. Rather than relying solely on TFEU provisions, Member States almost always rely directly on the Temporary Framework menu of state aid schemes (Table 2, Chart 2). Employment of Art. 107(2)(b) TFEU is quite rare and some of the Member States did not even request approval for such aid (individual or scheme). Thus, the Member States focus their state aid measures more on helping undertakings to overcome economic breakdown and saving the economies for restarting and re-boosting, rather than compensating for the consequences of particular public health interferences in the operation of the businesses.

The diversity of approaches of the Member States is also apparent in benefiting from different types of state aid. EU-wide, state guarantees have the highest share of the total amount of aid, but in some states (Bulgaria, Denmark, ${ }^{6}$ Cyprus, Malta, Romania, Slovenia, and Slovakia) direct grants are dominant.

\footnotetext{
${ }^{6}$ Regarding Denmark, figures for this country are partially influenced by specific schemes for mink fur producers, which did not occur on such a scale in other EU countries.
} 
Chart 1: Percentual share of COVID-19-related state aid to average gross domestic product at current prices calculated as the average value from 2019 and 2020

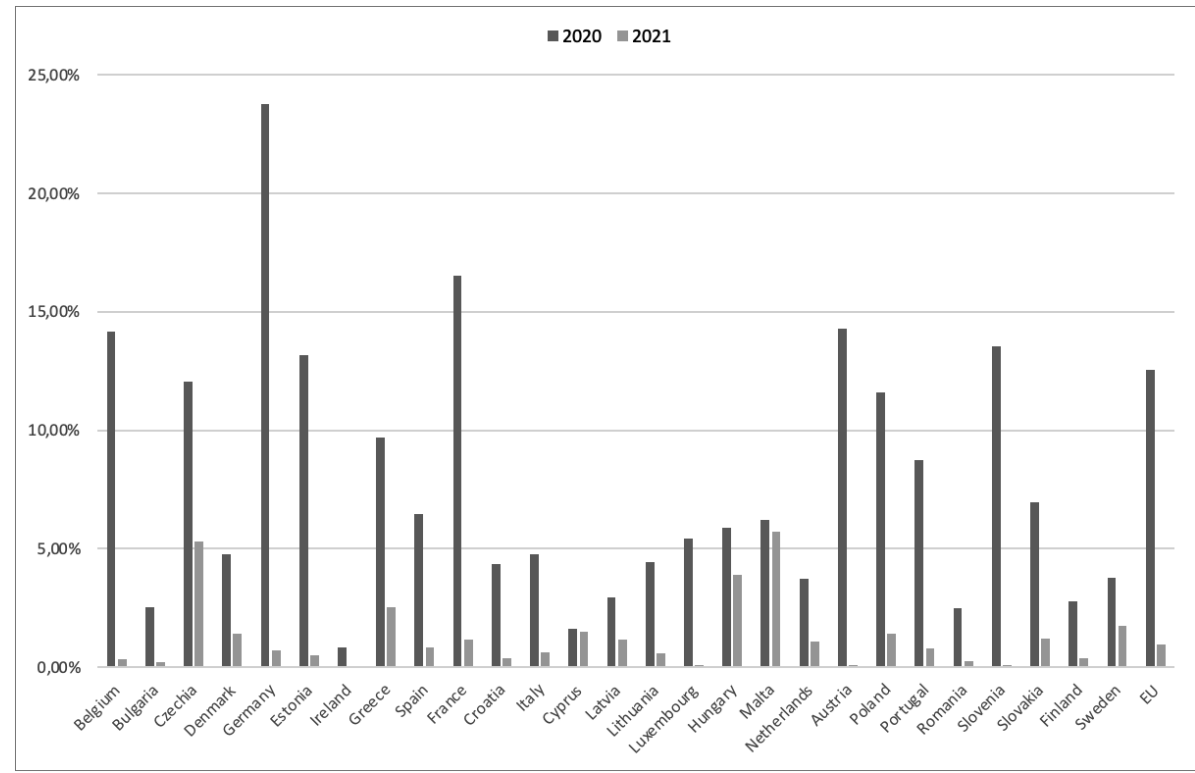

Source: (European Commission, 2021c, 2021b), authors

Table 2: Total amount of state aid within the measures approved in relation to the COVID-19 pandemic in 2020-2021 (in millions of euros) according to legal basis

\begin{tabular}{|l|r|r|r|r|}
\hline & Art. 107(2)(b) & Art. 107(3)(b) & Art. 107(3)(c) & $\begin{array}{c}\text { Temporary } \\
\text { Framework }\end{array}$ \\
\hline Belgium & 4,8 & 50903,0 & 0,0 & 16282,1 \\
\hline Bulgaria & 0,0 & 0,0 & 0,0 & 1663,1 \\
\hline Czechia & 37,6 & 76,5 & 0,0 & 38159,3 \\
\hline Denmark & 9617,0 & 4038,5 & 0,0 & 5846,6 \\
\hline Germany & 29218,0 & 30840,0 & 0,0 & 770610,0 \\
\hline Estonia & 20,0 & 0,0 & 0,0 & 3764,4 \\
\hline Ireland & 26,0 & 0,0 & 0,0 & 3159,0 \\
\hline Greece & 785,0 & 665,0 & 665,0 & 20486,3 \\
\hline
\end{tabular}




\begin{tabular}{|c|c|c|c|c|}
\hline & Art. 107(2)(b) & Art. 107(3)(b) & Art. $107(3)(c)$ & $\begin{array}{l}\text { Temporary } \\
\text { Framework }\end{array}$ \\
\hline Spain & 2550,0 & 500,0 & 0,0 & 83650,0 \\
\hline France & 1126,7 & 32 003,0 & 0,0 & 385970,0 \\
\hline Croatia & 11,7 & 0,0 & 0,0 & 2447,7 \\
\hline Italy & 976,0 & 2000,0 & 0,0 & 89754,2 \\
\hline Cyprus & 0,0 & 87,0 & 0,0 & 582,7 \\
\hline Latvia & 0,0 & 0,0 & 0,0 & 1216,8 \\
\hline Lithuania & 20,0 & 240,0 & 0,0 & 2181,1 \\
\hline Luxembourg & 0,0 & 0,0 & 0,0 & 3515,1 \\
\hline Hungary & 145,0 & 0,0 & 0,0 & 13619,2 \\
\hline Malta & 0,0 & 0,0 & 0,0 & 1568,2 \\
\hline Netherlands & 1233,7 & 12006,7 & 0,0 & 25786,5 \\
\hline Austria & 8150,0 & 275,4 & 0,0 & 47266,0 \\
\hline Poland & 3282,0 & 2450,0 & 0,0 & 64627,5 \\
\hline Portugal & 729,5 & 500,0 & 1333,0 & 17275,9 \\
\hline Romania & 5,4 & 0,0 & 0,0 & 6051,8 \\
\hline Slovenia & 205,0 & 0,0 & 0,0 & 6248,1 \\
\hline Slovakia & 29,8 & 0,0 & 0,0 & 7503,0 \\
\hline Finland & 470,0 & 0,0 & 0,0 & 7047,0 \\
\hline Sweden & 7603,5 & 0,0 & 0,0 & 18621,3 \\
\hline EU & 66246,7 & 136585,1 & 1998,0 & 1644902,8 \\
\hline
\end{tabular}

Sources: (European Commission, 2021b), authors 
Chart 2: Percentual share of the legal basis state aid within the measures approved in relation to the COVID-19 pandemic in 2020-2021

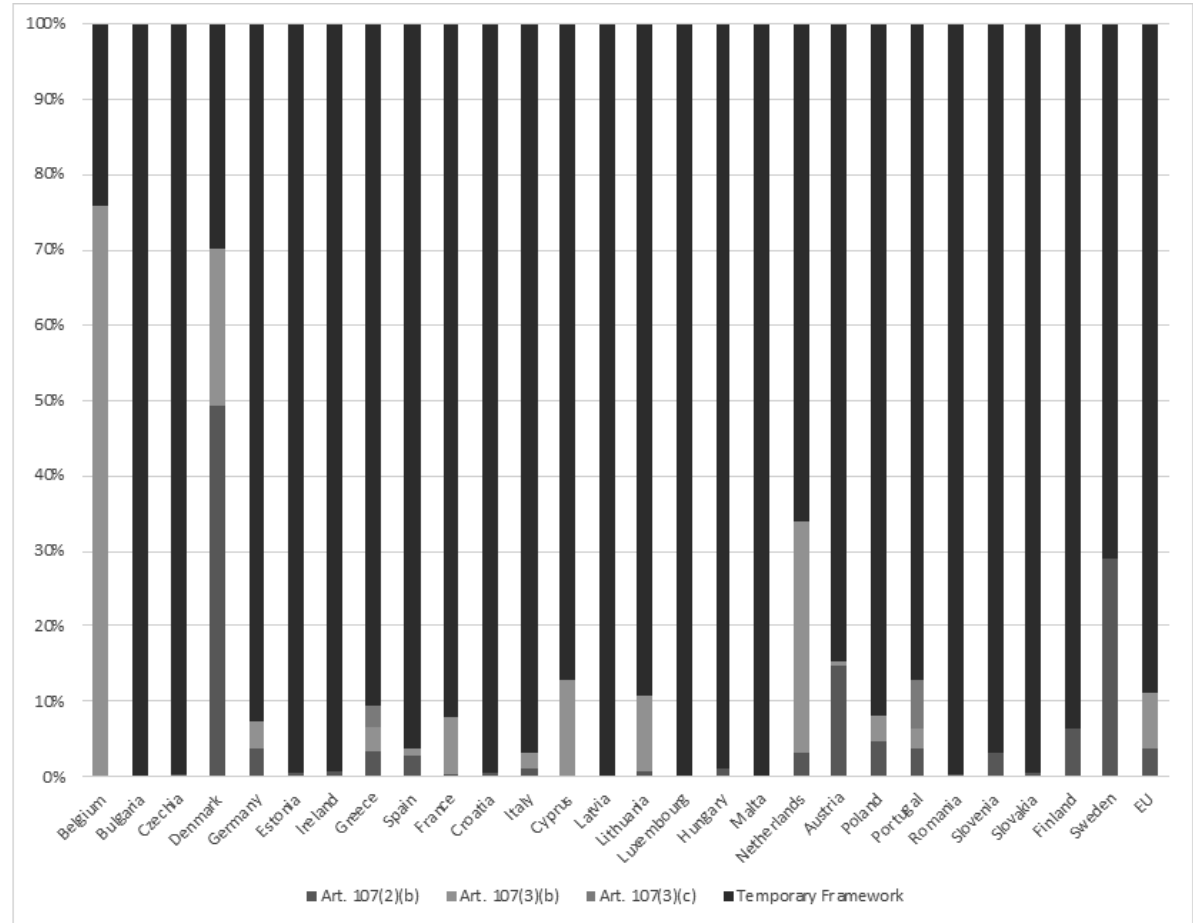

Sources: (European Commission, 2021b), authors 
Chart 3: Percentual share of the types of state aid within the measures approved in relation to the COVID-19 pandemic in 2020-2021

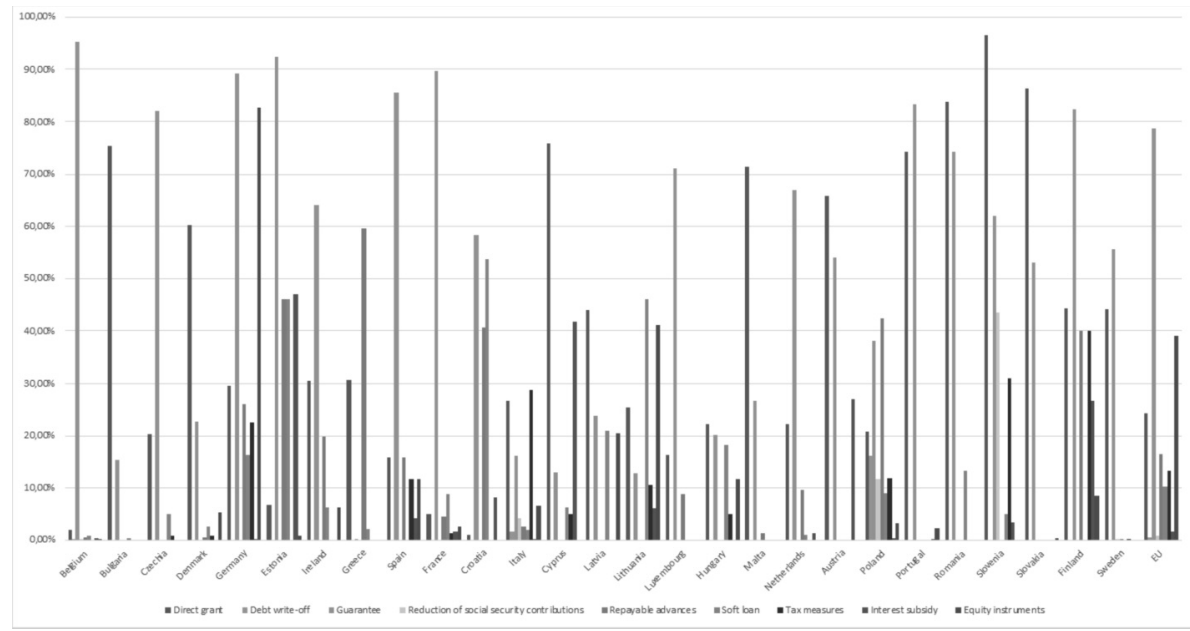

Sources: (European Commission, 2021b), authors

Private complaints both empower and constrain the Commission. On the one hand, private complaints help the Commission to detect non-notified state aid measures, and have been especially important in trade disputes over the grant of aid. On the other hand, dissatisfied with the Commission's treatment of their complaints, private parties have repeatedly challenged state aid decisions before the CJEU or the General Court ('GC') (Cini, 2021, p. 32). Referring to different approaches of the Member States, in the series of COVID-19-related cases launched by Ryanair, the GC found no violation of the principle of equal treatment, as the measures adopted were expressly permitted under Art. 107(3)(b) or (c) of the TFEU, were suitable for achieving the desired outcome and did not go beyond what was necessary in order to attain it. The difference in treatment was therefore in accordance with EU law ${ }^{7}$ and the argument of economic nationalism was rejected (Ryanair/Commission, T-388/20, § 94).

Along with explicit state aid schemes, some contracting authorities of the Member States can be tempted to "help" undertakings by the design of public

${ }^{7}$ E.g. judgment of 14 April 2021, Ryanair/Commission, T-388/20, ECLI:EU:T:2021:196 § 82; judgment of 14 April 2021, Ryanair/Commission, T-378/20, ECLI:EU:T:2021:194, § 68. 
procurement. The COVID-19 pandemic undoubtedly required immediate purchases of medical equipment and other tools necessary for solving urgent medical and sanitary occurrences, and therefore it allows restricted and limited forms of tendering. Kováčiková and Blažo showed that almost all Member States when realising limited tendering, awarded contracts to domestic suppliers. This appeared especially in relation to COVID-19 procurement, and despite quite clear Commission's Guidelines, their research proved that several EU countries employed limited tendering even in the second part of 2020 when it could have been expected that there would be a necessity for purchases of medical material and other goods necessary for the combat against the COVID-19 pandemic, and it could be expected that some cases of limited tendering would be challenged due to abuse of the "extreme urgency" clause (Kováčiková \& Blažo, 2020, p. 212). Due to the substantial rise in the number of limited tenders and lack of competition in a substantial number of tenders (Kováčiková \& Blažo, 2020, pp. 209-212), this situation can lead to tensions between public procurement and state aid that disrupt the presumption of the non-existence of state aid if public procurement is obeyed (Martinic \& Kozina, 2016, p. 226; Sánchez-Graells, 2021, pp. 329-330). Indeed, compared to massive state aid approved by the Commission, these public-procurement-introduced state aids can be deemed small or insignificant, which does not diminish their unlawfulness.

\section{CONCLUSIONS}

Since measures adopted by the public authorities protect the community in certain areas as a whole, the ECtHR confirmed the legality of their intrusion into running businesses, even though they cause certain damage to entrepreneurship. However, the undertakings cannot bear the entire burden of those measures, and according to ECtHR case law, at least one type of solidarity should be implemented. In the context of the EU legal environment, such compensatory or solidarity schemes fall under EU state aid rules. It must be stressed that EU state aid rules are not "policymaking" rules of the EU, i.e., in general, they are not designed for the EU to shape its own policy. These rules represent one of the safeguard tools created to protect the internal market from segmentation owing to encroachments of the Member States into free-market economies, and the Commission can only guide, monitor, control, direct, and shape some scope of state aid (Cini, 2021), but never create policy and establish schemes itself. This is one of the reasons why, apart from the Recovery and Resilience Facility of the EU, the answer of the Member States of the EU to COVID-19 in terms of state aid is not uniform. State aid measures vary regarding the scope, amount, legal basis, or type of state aid among the EU Member States. Not all Member States used Art. 107(2)(b) TFEU to compensate for the harm 
caused by restrictive public health measures. Indeed, the case law of the ECHHR does not require any specific form of relief from the burden caused by public health restrictions that have an impact on the operation of businesses, and thus state aid provided under any legal basis can meet the ECtHR's requirements. The COVID-19 pandemic, as well as the resulting public health restrictions and recovery measures, are examples of the EU Member States' dual obligations to the international community: public health restrictions adopted within the Member States' competence (Kiová, 2020), as well as the subsequent materialization of measures safeguarding human rights protection derived from the ECHR and its protocols, are examples of the EU Member States' dual obligations. Despite the different approaches of the Member States regarding COVID-19-related state aid measures, the $\mathrm{GC}$ rejected claims of the illegality of such a state of affairs due to alleged "economic nationalism". Therefore, uniformity of state aid measures, even in cases caused by the same exceptional occurrence, cannot be expected, notwithstanding the uniform guidance and frameworks provided by the European Commission.

\section{REFERENCES}

\section{Case law of international bodies}

\section{European Court of Human Rights}

Sporrong and Lönnroth v. Sweden (Plenary), app. nos. 7151/75 and 7152/75, 23 September 1982.

James and others v. the United Kingdom (Plenary), app. no. 8793/79, 21 February 1986.

Tre Traktörer Aktiebolag v. Sweden, app. nos. 10873/84, 7 July 1989.

Papamichalopoulos and others v. Greece, app. no. 14556/89, 24 June 1993.

Hentrich v. France, app. no. 13616/88, 22 September 1994.

Pinnacle Meat Processors Company and others v. the United Kingdom (dec.), app. no. 33298/96, 21 October 1998.

Ouzounoglou v. Greece, app. no. 32730/03, 24 November 2005.

Depalle v. France (GC), app. no. 34044/02, 29 March 2010.

Savickas and others v. Lithuania, app. nos. 66365/09, 12845/10, 29809/10, 29813/10, 30623/10, 28367/11, 15 October 2013.

Vékony v. Hungary, app. no. 65681/13, 13 January 2015.

Matczyński v. Poland, app. no. 32794/07, 15 December 2015.

Bélané Nagy v. Hungary (GC), app. no. 53080/13, 13 December 2016.

Werra Naturstein GMBH \& CO KG v. Germany, app. no. 32377/12, 19 January 2017. 
O'Sullivan McCarthy Mussel Development Ltd. v. Ireland, app. no. 44460/16, 7 June 2018.

Könyv-Tár Kft. and others v. Hungary, app. no. 21623/13, 16 October 2018.

\section{Court of Justice of the European Union}

Judgment of 11 November 2003, Spain/Commission, C-73/03, EU:C:2004:711.

Judgment of 29 April 2004, Greece/Commission, C-278/00, EU:C:2004:239.

Judgment of 23 February 2006, Atzeni and others, C-346/03 and C-529/03, EU:C:2006:130.

Judgment of 25 June 2008, Olympiaki Aeroporia Ypiresies/Commission, T-268/06, EU:T:2008:222.

Judgment of 9 June 2011, Comitato "Venezia vuole vivere"/Commission, C-71/09 P, C-73/09 P and C-76/09 P, EU:C:2011:368.

Judgment of 17 February 2021, Ryanair/Commission, T-238/20, ECLI:EU:T:2021:91. Judgment of 17 February 2021, Ryanair/Commission, T-259/20, ECLI:EU:T:2021:92. Judgment of 14 April 2021, Ryanair/Commission, T-378/20, ECLI:EU:T:2021:194. Judgment of 14 April 2021, Ryanair/Commission, T-379/20, ECLI:EU:T:2021:195. Judgment of 14 April 2021, Ryanair/Commission, T-388/20, ECLI:EU:T:2021:196.

Bouchagiar, A. (2021). State aid in the context of the COVID-19 outbreak, including the Temporary Framework 2020. In EUI Working Paper RSC (No. 3). https://doi.org/10.2139/ssrn.3796216

Cini, M. (2021). State Aid Control from a Political Science Perspective. In L. Hancher \& J. J. Piernas López (Eds.), Research Handbook on European State Aid Law (pp. 28-43). Retrieved from http://www.elgaronline.com/view/9781849802741. 00011.xml, 15 July 2021.

Cortese, B. (2020). State Aid Law as a passepartout: Shouldn't We Stop Taking the Effect on Trade for Granted? Bratislava Law Review, 4(1), pp. 9-18. https://doi.org/10.46282/blr.2020.4.1.194

EU. (2015). Council Regulation (EU) 2015/1589 of 13 July 2015 laying down detailed rules for the application of Article 108 of the Treaty on the Functioning of the European Union. In Official Journal of the European Union. European Union: OJ L 248, 24.9.2015, pp. 9-29.

EU. (2020a). Communication from the Commission Temporary Framework for State aid measures to support the economy in the current COVID-19 outbreak 2020/C $91 \mathrm{l} / 01$. In Official Journal of the European Union. OJ C 911 , 20.3.2020, pp. 1-9. 
EU. (2020b). Council Regulation (EU, Euratom) 2020/2093 of 17 December 2020 laying down the multiannual financial framework for the years 2021 to 2027. In Official Journal of the European Union. OJ L 4331 , 22.12.2020, pp. 11-22.

EU. (2020c). Council Regulation (EU) 2020/2094 of 14 December 2020 establishing a European Union Recovery Instrument to support the recovery in the aftermath of the COVID-19 crisis. In Official Journal of the European Union. OJ L 433I , 22.12.2020, pp. 23-27.

EU. (2020d). Regulation (EU, Euratom) 2020/2092 of the European Parliament and of the Council of 16 December 2020 on a general regime of conditionality for the protection of the Union budget. In Official Journal of the European Union. OJ L 433I , 22.12.2020, pp. 1-10.

European Commission. (2021). Case Search, retrieved from Competition Policy website: https://ec.europa.eu/competition/elojade/isef/index.cfm?clear=1\& policy_area_id=3, Accessed 15 July 2021.

European Commission. (2020). Case Search, retrieved from Competition Policy website: https://ec.europa.eu/competition/elojade/isef/index.cfm?clear=1\& policy_area_id=3, Accessed 15 July 2021.

European Commission. (2021a). Aid by main objectives in current prices, retrieved from State Aid Scoreboard 2020 website: https://webgate.ec.europa.eu/ comp/redisstat/databrowser/view/AID_SCB_OBJ/default/table?lang=en\&categ ory=AID_SCB_OBJ, Accessed 15 July 2021.

European Commission. (2021b). Coronavirus Outbreak - List of Member State Measures approved under Articles 107(2)b, 107(3)b and 107(3)c TFEU and under the State Aid Temporary Framework, retrieved from Competition Policy/The State Aid Temporary Framework website: https://ec.europa.eu/ competition-policy/system/files/2021-07/State_aid_decisions_TF_and_107_ 2b_107_3b_107_3c_0.pdf, Accessed 15 July 2021.

European Commission. (2021c). Gross domestic product at market prices, retrieved from Eurostat website: https://ec.europa.eu/eurostat/databrowser/view/ tec00001/default/table?lang=en, Accessed 15 July 2021.

Ferri, D. (2021). The Role of EU State Aid Law as a "Risk Management Tool" in the COVID-19 Crisis. European Journal of Risk Regulation, 12(1), pp. 176-195. https://doi.org/10.1017/err.2020.71

Kiššová, S. (2020). Európska únia v boji proti COVID-19. COMENIUS Časopis, (1), pp. 28-38.

Kováćiková, H., \& Blažo, O. (2020). Limited tendering- A barrier to get the best value for money or effective solution for extraordinary situations? International and 
Comparative Law Review, 20(2), pp. 192-214. https://doi.org/10.2478/iclr2020-0024

Martinic, S., \& Kozina, A. (2016). Europe 2020' and the eu public procurement and state aid rules: Good intentions that pave a road to hell? Croatian Yearbook of European Law and Policy, 12(1), pp. 207-249. https://doi.org/10.3935/cyelp. 12.2016.238

Sánchez-Graells, A. (2021). State aid and EU public procurement: more interactions, fuzzier boundaries. In L. Hancher \& J. J. Piernas López (Eds.), Research Handbook on European State Aid Law (pp. 329-346). https://doi.org/10.4337/97817 89909258.00024

Thomson, S., \& Ip, E. C. (2020). COVID-19 emergency measures and the impending authoritarian pandemic. Journal of Law and the Biosciences, 7(1). https://doi.org/10.1093/jlb/lsaa064

Van Hove, J. (2020). Impact of state aid on competition and competitiveness during the COVID-19 pandemic: an early assessment. Brussels: European Union. 